\title{
The Place of Religion in Education:
}

\section{A Contemporary Nigerian Perspective}

\author{
Peter O. Chineke \\ Pontifical and Royal University of Santo Tomas (UST), Manila, Philippines
}

\begin{abstract}
The Nigerian society has been plagued by persistent religious conflicts alongside the problem of insecurity for some time now. This is not a new development, but it has worsened since the last five years with the emergence of the Boko Haram Islamic group. This group claims to be responsible for most violent activities in the northern part of the country for the past few years. Judging from the nature of their activities, Boko Haram, an Arabic phrase which literally means that "western education is forbidden", is among other factors, largely rooted in religious intolerance. The challenges posed by this group since 2010 have defied all logic and rationality, leaving Nigerians with deep concerns for the unity of their country in the present era. Why has religion, albeit a formidable unifying element, become an instrument of various kinds of menace, destruction of lives and properties? It appears to have even caused many to wonder about the quality of education and expertise of the Nigerian polity and governance. It must also be noted that most of these problems with Boko Haram have their roots in the northern part of the country which is predominantly Islamic in religion. Religion has been awfully misrepresented and used as an excuse for all kinds of evil. This paper examines the place of religion in education from the perspective of the contemporary Nigerian society. It also explores how religion can still be used as a paradigm for restoring the sanctity and dignity of education, promote its morality and actualize its objectives in the society. The paper furthermore summons religious leaders to devise significant ways, such as interfaith dialogues and activities to enhance a sustained education in the country.
\end{abstract}

Keywords: Boko Haram, security, Nigeria, dialogue, education, religion

\section{Introduction}

The contemporary situation of Nigerian nation is very adverse to the integral development of the human person, especially in the area of formal education and socio-civic advancement of an individual. This problem is most often seen as being rooted in the political differences and intransigence among the political elites of the major ethnic groups of Hausas, Yorubas and the $\operatorname{Ibos}^{1}$. In as much as this is part of the problem, with a critical study of the parallel developments of the recent security situation in the country, one would easily realize that there are religious influences involved which are mostly the significant factors behind the whole problem. These religious influences would have Christian and Muslim religions at the crux of the situation.

Peter O. Chineke, Bachelor of Philosophy (Ph.B.), College of Ecclesiastical Faculties, Pontifical and Royal University of Santo Tomas (UST).

Correspondence concerning this article should be addressed to Peter O. Chineke.

1 Onu, G. (2001). "Ethnicity and Conflict Management: A Case Study of MASSOB Movement in Nigeria." At http://www.unesco.org/most/crossroadsonu.htm (02/07/2015). 
Religion inspires violence and shatters the social harmony among people of different religious affiliations. Nevertheless, as a "two-edged sword", it could also serve as a vital tool for the consolidation of social harmonies and peaceful coexistence among peoples. ${ }^{2}$ However, between the two possible applications of religion stated above, the former is not far from what religion seems to mean in the contemporary Nigerian society.

\section{Current Security Situation of the Nigerian Nation}

National security has been problematic in the Nigerian society. Since after the Nigeria-Biafra war in 1967-1970, the nation has continued to experience a constant state of political and religious unrest leading to a condition of persistent religious and political conflicts. This has caused irreparable damages in the areas of national unity and infrastructural advancement and the entire economy at large. Tragically, it has had adverse effects on religious freedom or freedom of worship and has deprived the populace of many among fundamental human rights. The Nigeria-Biafra war destroyed inter-ethnic confidence and brotherhood, especially as regards national politics, inter-regional business investments. Most importantly, the unity of the country in her diversity, which the Nigerian nation boasts of in her national pledge, appears to be a mere mirage.

The word security has to do with freedom from danger, anxiety and fear; a situation which shows that a country is not exposed to internal sabotage or external attack (Amadu, 1989). ${ }^{3}$ In the broader sense, security is seen as the struggle to secure the most basic necessities of life, such as food, fuel, medicine and shelter (Obafemi, 2006). ${ }^{4}$ Any social unrest arising from the absence of these facilities (according to Ushe Mike, 2012) can lead to human security problems. From the above text, national security therefore means,

The ability of nations to prevent all forms of threats to its survival ranging from external aggression to threats of economic, political, military and environmental insecurities, whilst grappling with the challenges of nation-building and good governance. (Gbenga, 2006) ${ }^{5}$

National security is the aggregate of the security interests of all individuals, communities, ethnic groups and political entities to guarantee safety and security, prosperity of individuals and institutes within a nation (Ushe Mike, 2012). ${ }^{6}$ The issue of national security must necessarily be present to guarantee the social survival and economic advancements of any nation. In this capacity, the just distribution of political power, economic sustainability, diplomacy and projection of power becomes a necessity.

\section{Formal Education in the Contemporary Nigerian Society}

As a very complex subject, education is quite difficult to define. However, there are various definitions of education by scholars in diverse fields of expertise and at different times. These definitions are all relevant but none has been universally accepted as the standard definition of education. Nevertheless, Lannap and

\footnotetext{
${ }^{2}$ Ekanem, Samuel Asuquo and Ekefre, Ekeng Nyong (2013). "Education and religious intolerance in Nigeria: The need for essencism as a philosophy.” Journal of Educational and Social Research, Vol. 3(2), 303-310.

${ }^{3}$ Ushe, Mike Ushe (2012). "Religious conflicts and education in Nigeria: Implications for national security." International Journal of Educational Research and Development, Vol. 1(2), 011-022.

${ }^{4}$ Ushe, Mike Ushe (2012). "Religious conflicts and education in Nigeria: Implications for national security." International Journal of Educational Research and Development, Vol. 1(2), 011-022. (12).

${ }^{5}$ Ushe, Mike Ushe (2012). "Religious conflicts and education in Nigeria: Implications for national security." International Journal of Educational Research and Development, Vol. 1(2), 011-022. (13).

${ }^{6}$ Ushe, Mike Ushe (2012). "Religious conflicts and education in Nigeria: Implications for national security." International Journal of Educational Research and Development, Vol. 1(2), 011-022. (14).
} 
$\mathrm{Kazi}^{7}$ defined education as the oldest discipline in human history, which deals with the art of imparting, acquiring knowledge through teaching and learning, especially at school or similar institution. This definition is adopted in this paper because it is precise and assimilating of the key points about formal education.

Education is certainly one of the sectors given the highest priority by any government for the all-inclusive development of a society. It is the central nub where other sectors like economy, health, tourism, industry, aviation, energy/power, etc. revolve and through which they find their place in the society. However, the morality and sanctity of education determine the extent to which education can attain its goal of shaping the entire aspects of the life of any society. On the other hand, when the issue of the sanctity and morality of education is raised, religion is rightfully invited to play its indispensable role. The role of religion is very vital to the advancement of education and the impingement of educational values in the entire life of peoples.

Since education is the basis of development, it seems to me that the Nigerian educational system needs radical religious intervention. The reason for this intervention is clearly seen in our day to day experience of the dysfunctional nature of education at all levels in the Nigerian nation. On the daily basis, the Nigerian educational system displays an increasing rate of moral decadence and corruption that destabilizes and stagnates the developmental efforts of well-meaning Nigerians. Examination malpractices, plagiarism, forged educational certificates backed-up by educational institutions, indiscriminate award of academic honors, and forgery of educational certificates at all levels of education have destroyed our educational system in Nigeria. Ironically, many African nations still send their children to study in Nigeria. This is a threat to the future of the African continent. It is a clear manifestation of the declination and decadence of the educational system and its inherent values in our contemporary societies especially in Nigeria.

However, in the Nigerian context, it is not unusual that the notion of western education comes to mind at the mention of education. Nonetheless, traditional and Islamic educations sometimes are also thought of. They are also types of religious education.

\section{Religion and Religious Intolerance in Nigeria}

Religion is very prominent in human history that any attempt to ignore it would probably fail. It is as old as human beings and would remain on earth as long as there is human existence. The contributions of religion in human civilizations, especially in the areas of social development, interpersonal and international cooperation, mutual understanding among peoples and most importantly, educational developments are quite enormous.

The concept of religion cuts-across almost all boundaries of human cognitive experience and therefore, is notoriously difficult to define. Scholars, including philosophers, theologians, students and teachers of religion have made a lot of attempts to come up with a more universally acceptable definition of religion but to no avail. Nevertheless, there are some definitions that more or less, tell us much about the concept of religion. In as much as there are other good definitions, the definition given by Paul James and Peter Mandaville has been adopted by me:

Religion is a relatively bounded system of beliefs, symbols and practices that address the nature of existence, and in which communion with others and Otherness is lived as if it both takes in and spiritually transcends socially-grounded ontologies of time, space, embodiment and knowing.

\footnotetext{
${ }^{7}$ Ushe, Mike Ushe (2012). "The role of Christian religious education in resolving political violence in the northern states of Nigeria.” Journal of Research in Education and Society, Vol. 3, No. 1, 41-53.
} 
Paul and Peter intended this definition to get away from the modernist dualisms or dichotomous understandings of immanence/transcendence, spirituality/materialism, and sacredness/secularity. ${ }^{8}$

The above definition fits best to my understanding of religion, especially for its identification with ontological and social elements of human existence.

As stated earlier, the issue of religious intolerance in Nigeria greatly threatens the nation's unity and socioeconomic development for a long time now. Some individuals and groups usually claim that religious intolerance in Nigeria dates back to the time of the Nigeria-Biafra war in the 1960s, others believe it started some years ago when the political leadership of the country appears to have been revolving within certain geopolitical zones or ethnicities while excluding other geopolitical zones. However, popular opinion has it that the problem began with the unreflective amalgamation of peoples and tribes with little or no similarities in race, culture, traditions, beliefs and mentalities into one country by the British colonial masters in 1914. This amalgamation was spearheaded by Frederick Lugard, a British soldier and colonial administrator and the first governor of Nigeria who unified the country through an indirect rule.

More so, the multi-cultural, ethnic diversity of the Nigerian people, which is a major factor in the religious affiliation of Nigerians, is an important topic to investigate. As a country divided into two major regions (North and South) with each of the two regions further subdivided into three geopolitical zones (North: North-East, North-West and North-Central; South: South-East, South-West and South-South), the people are socio-culturally attached to each other in a way that each zone is densely dominated by a particular religion of either Christianity or Islam. These two are the major religions in Nigeria. The southern regions are dominated by Christianity while the Northern regions are vastly dominated by Islam. The traditional religions otherwise often addressed as African Traditional Religions (ATR) ${ }^{9}$ are slightly present across the country, but are more visible in the south-west geopolitical zone of the Yoruba tribe.

On the other hand, intolerance by definition is the inability to bear with one another for reasons of differences either in opinion, belief or knowledge as an indispensable factor for any meaningful progress and development of a nation, country or culture. ${ }^{10}$

With an updated knowledge of the current state of affairs in Nigeria, one will truly understand that the issue of religious intolerance has worsened since the past few years. Some of the actions that display the height of this religious intolerance in Nigeria often occur under the guise of political sectarianism. Moreso, the agitations for the implementations of Sharia law and Islamic banking system in the country by some individuals and groups like Boko Haram are also clear manifestations of religious intolerance. This is because such ideologies are purely Islamic and favor only the Muslims.

However, Nigeria is not an Islamic country. It is a democratic republic with people of diverse religious affiliations. As such, it has no state religion, neither does it forbid freedom of worship. Therefore, any religious ideology that is not acceptable by the majority of the adherents of the religions practiced in Nigeria is a clear expression of religious bigotry. This is so despite the possible economic and developmental advantages and

8 Paul J. and Peter M. (2015). “Defining 'Religion’ (Wikipedia)”, at http://www.democraticunderground.com/12646299 (20/05/2015).

${ }_{9}^{9}$ Omoregbe, Joseph I. (1999). Comparative Religion, Christianity and other world religions in Dialogue: Christianity, Judaism, Islam, African Traditional Religion, Hinduism, Buddhism, Jinism, Confusianism, Taoism and Shintoism. Joja Educational Research and Publishers Limited, Nigeria.

${ }^{10}$ Fan A. F., Jummai J. and Onuoha N. (2014). "Towards proffering a solution to the persistent religious intolerance which is a bane of development in Nigeria.” Global Advanced Research Journal of Educational Research and Review, Vol. 3, No. 2, 022-027. (023). 
values of such ideology.

Religious intolerance is a big part of Nigerian national socioeconomic problems. It is largely responsible for the stagnancy in the nation's developmental projects and lots more. Since the recent times, Nigeria has experienced a lot of challenges in many areas of human endeavour, especially in the education and health sectors, but the resilient attitude of the Nigerian people has always kept the masses above their problems.

\section{Boko Haram Group and the Spate of Terrorism in Nigeria}

The first things that come to the mind of an average Nigerian at the mention of Boko Haram are "Violence! Violence!! Violence!!!”.

Boko Haram is an Islamic group known as “Jama’atul Alhul Sunnah Lidda’ Wat, Wal Jihad” meaning a group committed to the propagation of Prophet Mohammed's teachings and the Jihad (Meehan \& Spaier, 2011) ${ }^{11}$. The literal translation of Boko Haram is "Western education is forbidden". It was founded in 2002 by an Islamic cleric named Mohammed Yusuf in response to Nigeria’s democratic transition, nationalism and western influence. ${ }^{12}$

In common usage, the Boko Haram label actually describes a complex, multifaceted insurgency composed of a number of different factions, cells, and criminal groups exhibiting varying degrees of coordination with the wider movement. $^{13}$

Nevertheless, many people argue that the real reason(s) behind the existence of this group and their attacks to human lives and properties for about half a decade now has little or nothing to do with the presence of western education in Nigeria. This argument is supported by the fact that Nigeria, as one of the largest economies in Africa, is also one of the greatest educational hubs of the African continent. Nigerian Muslims are a big part of the political leadership of the country. They have among them intellectuals and academicians trained in and after the western order of education that specialize in different capacities serving the country and the world at large.

Though Boko Haram has existed long before 2009, it came to the public awareness as an Islamic militant group in early 2009. Since then, it has claimed responsibility for many terrorist attacks against the populace in the northern regions of Nigeria. This group, while relentlessly pursuing their ideology of propagating Prophet Mohammed's teachings and the Jihad, has been responsible for several heinous activities like bombing, arson, random shooting in public places like market, church, schools etc.

Furthermore, the spate of terrorist attacks in the northern Nigeria has made the region highly insecure. A good number of inhabitants flee their homes daily to the refugee camps in neighboring countries like Niger, Cameroon, etc. for safety. These attacks are not limited to human lives. Several private and public properties have been damaged by this violent group of people. Some of these include the bombing of the Nigerian Police Headquarters in Abuja in 2011 which was followed by the bombing of the United Nations House also in Abuja on August 26, 2011. ${ }^{14}$

\footnotetext{
11 Babatunde, M. M., Unwana-Obong U. D. and Olanrewaju M. K. (2014). "Historical Antecedents of Boko Haram Insurgency and Its Implications for Sustainable and Educational Development in North Central Nigeria.” Journal of Education and Practice, Vol. 5, No. 22, P. 61.

12 The Clarion Project (2015). Boko Haram Special Report: www.clarionproject.org/category/tags/boko-haram/.

13 Mike Smith, Boko Haram: Inside Nigeria’s Unholy War (New York: I. B. Tauris, 2015), 12-13, 137-138; and Marc-Antoine Pérouse de Montclos, “Nigeria's Interminable Insurgency? Addressing the Boko Haram Crisis," Chatham House (September 2014), 11-12, http://www.chathamhouse.org/publication/nigerias-interminable-insurgency-addressing-boko- haram-crisis.

${ }_{14}$ Ome, Emmanuel M. and Ani, Casimir (2015). "Re-Examining Religious Insecurity in the Africa State: The Menace and Security Challenges of Boko Haram in Nigeria.” Open Journal of Political Science, Vol. 1, No. 1, 95-101.
} 
Boko Haram has often claimed responsibility for these problems wreaking havocs which has attracted the attention of international communities and groups especially the media.

Some of the deadliest attacks of the Boko Haram Islamist group in parts of the Northern Nigeria since $2011^{1516}$

May 29, 2011

August 26, 2011

November 4, 2011

December 25, 2011

January 20, 2012

April 8, 2012

June 17, 2012

August 7, 2012

December 25, 2012

February 8, 2013

March 18, 2013

June 9, 2013

July 6, 2013

August 12, 2013

September 12, 2013

September 19, 2013

September 29, 2013

January 26, 2014

February 14, 2014

February 15, 2014

February 25, 2014

April 14, 2014

April 15, 2014

May 5, 2014

May 20, 2014

June 2, 2014

June 20-23, 2014

July 23-25, 2014

July 22, 2014

November 28, 2014

December 13, 2014

January 18, 2015

March 7, 2015

March 8, 2015

July 1, 2015

July 2, 2015

July 6, 2015
Bomb explosions killed 15 people in Bauchi and Abuja during the swearing in of Goodluck Jonathan as the newly elected president.

A bomb attack killed 21 people in the United Nations building in Abuja.

About 150 people are killed in a series of attack which Boko Haram claimed responsibility of.

Bomb attacks and shootings by Boko Haram left 41 people killed on a Christmas day in Christian Churches in North East Nigeria.

Boko Haram killed 183 people in Kano State.

A bomb attack at a church in Kaduna left 38 people dead.

Bomb attacks in three churches in Kaduna killed 19 worshippers.

Boko Haram killed 19 people in a raid at a church in Kogi State.

Boko Haram killed 27 Christians in Maiduguri and Potiskum.

9 women Polio vaccinators are killed by a group suspected to be Boko Haram.

A bus bombing left about 65 people dead in Kano state.

Boko Haram killed many children in Maiduguri and 13 students and teachers in Damaturu.

Boko Haram killed more than 42 at a state school in Yobe State.

An attack at a Mosque in Maiduguri killed 56 worshippers.

40 Soldiers are ambushed and killed by Boko Haram in the Northeast Nigeria.

Boko Haram claimed a bomb attack at Benisheik which left about 161 civilians dead.

Boko Haram gunmen attacked a state college in Gujba and killed more than 50 students.

About 138 people are killed by a suspected Boko Haram group in Northern Nigeria.

About 121 Christians are killed by Boko Haram militants in Konduga, Borno State.

About 106 people are killed by Boko Haram gunmen in Izghe, Bornu state.

Boko Haram massacred 59 students at Federal Government College in Yobe state.

A twin bomb attack left more than 88 people dead in Abuja.

About 276 school girls are kidnapped at Chibok in Bornu state by the Boko Haram group.

Boko Haram attacks two neighboring towns of Gamboru and Ngala both in Bornu State and killed about 300 people.

About 118 villagers are killed by car bombs in Jos, Plateau state.

About 200 Christians are killed by Boko Haram in some villages in Bornu state.

Boko Haram kidnapped about 91 women and children and killed about 70 others.

A series of attacks in the Middle Belt left about 171 people dead and many others severely injured.

Boko Haram raided Chibok town and killed about 51 people.

About 120 Muslim followers of the Emir of Kano, Muhammad Sanusi II, are killed during a Boko Haram suicide bombing and gun attack in Kano.

Boko Haram kidnapped about 185 people and killed dozens at Gumsuri, Bornu state.

More than 80 people are kidnapped by Boko Haram militants and others killed in neighboring North Cameroon town.

A suicide bomb explosion left about 54 people dead and more than 143 wounded after which Boko Haram formally declared allegiance to the Islamic state.

On election day, gunmen raided a polling unit and killed 15 voters, including a house of assembly candidate for Dukku in Gombe state.

Multiple Mosques in Kukawa are attacked, 48 men and boys are killed and about 17 wounded.

Also in Mosques at Kukawa, about 97 people, mostly men are killed while many women and young girls are killed in their homes. Dozens are left wounded.

A twin bomb attack killed about 44 people in the city of Jos.

15 Ogege, S. O. (2013). “Insecurity and Sustainable Development: The Boko Haram Debacle in Nigeria.” American International Journal of Social Science, Vol. 2, No. 7, PP. 84-85.

16 Wikipedia (2015). "Timeline of Boko Haram Insurgency." At https://en.wikipedia.org/wiki/Timeline_of_Boko_Haram_insurgency: September 27, 2015. 
The above mentioned attacks are just a tip of an iceberg of the activities of Boko Haram Islamist sect in the Northern Nigerian since 2011. There are various opinions and speculations regarding the mission of the Boko Haram group since its inception. Some of these opinions have been proved wrong by the wide-ranging nature of the group's activities. A good example is the idea that Boko Haram was particularly formed to frustrate the immediate past administration. In as much as the activities of this group worsened during the tenure of the immediate past Jonathan-led administration, one could also understand that the insurgency existed before Goodluck Jonathan became the president of Nigeria. It has also continued its violent activities, even four months after Jonathan left office.

However, a widespread opinion of the mission of the Boko Haram Islamist group is the idea that it is fundamentally an "Islamist extremist group committed to turning Nigeria into an Islamic nation". It is a blind course, because Nigeria is too religiously diversified that such a mission, if true, can never be accomplished.

\section{Current Nigerian Government and Boko Haram Insurgency}

Boko Haram is not an offshoot of the immediate past administration of Nigeria, neither was the administration the mastermind of the insurgency. It existed before the Jonathan-led administration assumed power in May 2010 and again in May 2011. But the violent activities of the Boko Haram group during the time of the immediate past administration escalated.

The Goodluck Jonathan-led administration fought the insurgency relentlessly, but was weak enough both to terminate the insurgency and to stop their numerous atrocities. This was the most significant reason why Nigerians during the last general elections in March 2015, went out en masse to elect a former military general, Muhammed Buhari who is believed to be the only presidential candidate during the elections to have the military experience and prowess to exterminate the group and their activities in the Northern part of the country.

The fundamental failures of the Nigerian governments have been among the most important drivers of the religious radicalism that has metastasized throughout the country since the 1980s. Countering violent extremism will require addressing the root causes, the majority of which lack readily available military solutions. Maneuvering the levers of a deeply troubled bureaucracy to accomplish those ends promises to be the most difficult component in the fight against Islamist militancy ${ }^{17}$.

Judging from the dispositions of the current administration towards issues of national security, especially as regards Boko Haram insurgency, there is some hope that the Buhari-led administration might succeed in annihilating Boko Haram insurgency from the country but it could possibly not be any soon.

\section{The Place of Religion in Nigerian Educational System}

Religion and education go hand in hand in the enlightenment and proper formation of the human mind. They have a substantial affinity that one might lose its meaning and place in the society when detached from the other. Their essences, values and impacts on any society are dependent upon the extent to which they are approached simultaneously. Religion and education are vital tools which, when fully harmonized, could liberate the contemporary man from irrational propagation of false ideologies.

Therefore, there should be a purely academic exercise of understanding the intersection of religion and

\footnotetext{
${ }^{17}$ Matthew B. (2015). "Nigerias' Critical Juncture: Boko Haram, Buhari, and the Future of the Fourth Republic.” Small Wars Journal, Vol. 1, No. 1, P. 6.
} 
education as a twin-concept in which one is continually supported and enhanced by the other.

On the other hand, religious creeds according to Albert Ellis, encourage some of the most uncivilized kinds of thoughts, emotions, and behaviors and favor severe manifestations of neurosis, borderline personality states, and sometimes even psychosis. ${ }^{18}$ However, this is religion without education; because, religion reasonably understood is religion well practiced.

Nonetheless, it is quite regrettable that since the recent past, religion, especially the Islamic religion has often been construed as the root cause of violence in Nigeria. This violence, however, is not restricted to religious intolerance, but extends to political crises and endless quest for political powers. Islam has not only been construed as such, but it has been practically represented as such mostly by the activities of the Boko Haram group and the political fat cats who have been accused of financing the group and their activities.

The Boko Haram group identifies itself as "Boko Haram Islamic group". Islamic religion in the contemporary Nigerian society has been drastically misrepresented, misinterpreted and exploited. The values of religion in general which the natural mind would think of, such as solidarity, compassion, harmony, humanitarianism, peaceful coexistence, communality and all forms of justice are now severely detached from the meaning of religion (Islam) in the contemporary Nigerian society.

The Boko Haram uprising in the northern Nigeria is one of the worst attacks on religion in the Nigerian history. Islam has been given a lot of meanings which call for urgent clarifications by Muslim leaders. However, it is very unfortunate that many analysts and media personnel usually reduce the Boko Haram insurgency as a problem rooted in political extremism and selfish interests of some political tyrants who dominate the civil government of the country. This view is not totally wrong, but it seems to have brutally neglected the major reason upon which ground the group was founded-religious intolerance.

"The most heinous and the most cruel crimes of which history has record have been committed under the cover of religion”... Mohandas Gandhi.

\section{Suggestions}

In a bid to proffer any possible way forwards for the contemporary Nigerian situation through the incorporation of religious values in the nation's educational system and promotion of intra-religious and inter-religious dialogues, this study proffers the following suggestions:

Unity in diversity: Diversity is a gift of nature. It is important to understand that Nigeria is a multicultural society with people of religious and cultural differences. Therefore, to continue as a single nation, the people really have to understand each other and use their different gifts and talents in developing their country. ${ }^{19}$

A government commission: There is a need for a government Inter-Religious commission, which would have its presence at all the levels of the civil government. This commission would be responsible in working out modalities for not just inter-religious, but also for intra-religious tolerance among the peoples. ${ }^{20}$

Evangelization and dialogue rather than religious extremism and proselytization: Religious extremism is a threat to any nation. Its effects on the economy and holistic development of any nation are quite terrific. Thus,

${ }_{18}$ Albert E. (2001). “Religious Quotes: Religion in General.” at http://humanismbyjoe.co/religion-quotes/ (20/05/2015).

19 Fan A. F., Jummai J. and Onuoha N. (2014). "Towards proffering a solution to the persistent religious intolerance which is a bane of development in Nigeria." Global Advanced Research Journal of Educational Research and Review, Vol. 3, No. 2, 022-027. (026).

${ }^{20}$ Omotosho A. O. (2003). "Religious Violence in Nigeria-The causes and solutions: an Islamic Perspective." Swedish Missiological Theme, Vol. 1, No. 1, 15-31. 
there is a great need for Nigerians, irrespective of religious affiliations, to desist from religious extremism. This will contribute to their survival as a nation. Also, it could yield a better result if hate speeches and other actions that stimulate religious intolerance and extremism are made punishable by law.

Furthermore, the practice of persuading other people to join one's faith is a height of ignorance. It is religious radicalism. Some individuals and groups are prone to blaspheming the other religions or religious denominations. Worst still, others do this by violent means or threat. This is anti-religious. It has never yielded any positive result to the perpetrators.

Evangelization and dialogue are effective, human and ideal. If they should be preferred to proselytization, religion would be rightly represented and practiced. Our freedom of worship as a people is both a fundamental human right and a big part of the national constitution.

Intra-religious and inter-religious dialogues: Intra-religious and inter-religious dialogues are twin-concepts. They supplement each other. Religious leaders of both Christianity and Islam in Nigeria would make a lot of success in restoring the dignity and sanctity of religion in the country's educational system through many ways. First, organizing internal dialogues among themselves and with the common members of their religions to resolve in-house issues within themselves would be a good development. The next step would be engaging with other religions for inter-religious dialogues. Intra-religious dialogue is sometimes, a prerequisite for a successful inter-religious dialogue. This is because charity begins at home.

Religious education in schools and colleges: The practice of including some religious subjects in secondary schools could produce more positive results if extended to the universities and colleges across the country. This is especially in public schools. It could be in the form of a "comparative religion" where every religion practiced in the country would be satisfactorily explained to the students especially their basic tenets and philosophies. This would boost inter-religious understanding among students.

Moreover, another effective means through which religious tolerance could be encouraged among students is by inter-school sports competitions and academic exercises among schools and colleges. ${ }^{21}$

These suggestions, including the advancement and promotion of general awareness about critical thinking, skills related to radicalization, ${ }^{22}$ religious freedom and tolerance should be promptly considered to efficiently, restore religion and its inherent values in the educational system of Nigeria.

\section{Conclusion}

From the above discussion, one can observe that religion has a fundamental role to play in the Nigerian educational system. It impinges its moral values on individuals, especially young people. More so, religion can serve as a paradigm for the restoration of the sanctity and dignity of education. It can achieve this end through discouraging and reducing corrupt practices of academic dishonesty such as plagiarism, fakery and forgery of educational certificates.

Consequently, there is the concomitant effect of academic bastardization of individual citizens, especially the political class, examination malpractices, and so on. When rightly allowed to assume its rightful position in the educational formation of individuals, religion promotes religious tolerance and destroys the spirit of

\footnotetext{
${ }^{21}$ Ushe, Mike Ushe (2012). "Religious conflicts and education in Nigeria: Implications for national security.” International Journal of Educational Research and Development, Vol. 1(2), 011-022.

${ }_{22}$ Ekanem, Samuel Asuquo and Ekefre, Ekeng Nyong (2013). "Education and religious intolerance in Nigeria: The need for essencism as a philosophy.” Journal of Educational and Social Research Vol. 3 (2), 303-310. (309).
} 
violence against other religions and religious denominations.

Finally, to improve our security situation in Nigeria and advance our educational systems, to restore the meaning, sanctity and dignity of religion, to eradicate religious intolerance, and to stamp out terrorism and restore religion into its rightful place in education, every Nigerian irrespective of religious affiliation, cultural orientation, educational attainment, social class and so on, should have a quota to contribute. All hands must be on deck! Because according to Saint John Paul II, no one is too poor that he or she has nothing to offer. Nevertheless, the civil government and religious leaders should work relentlessly and harmoniously until there are significant improvements at all levels.

\section{References}

Akilu, A. M., \& Mu'azu, A. S. (2015). From criticism to extrimism: An analysis of Boko Haram’s approach to modernism. International Knowledge Sharing Platform: Research on Humanities and Social Sciences, 5(8), 20-28. Retrieved from http://www.iiste.org/Journals/index.php/RHSS/article/view/21940/22293

Albert, E. (2001). Religious quotes: Religion in general. Retrieved May 20, 2015, from http://humanismbyjoe.co/religion-quotes/

Babatunde, M. M., Unwana-Obong, U., \& Olanrewaju, M. K. (2014). Historical antecedents of Boko Haram insurgency and its implications for sustainable and educational development in north central Nigeria. Journal of Education and Practice, 5(22), 59-65. Retrieved from http://www.iiste.org/Journals/index.php/JEP/article/viewFile/14542/14851

Ekanem, S. A., \& Ekefre, E. N. (2013). Education and religious intolerance in Nigeria: The need for essencism as a philosophy. Journal of Educational and Social Research, 3(2), 303-310.

Ewetan, O., \& Urhie, E. (2014). Insecurity and socio-economic development in Nigeria. Journal of Sustainable Development Studies, 5(1), 40-63.

Falade, D. A., \& Falade, M. (2013). Development of core values for national integration in Nigeria. International Journal of Humanities and Social Science Invention, 2(7), 57-63.

Fan, A. F, Jummai, J., \& Onuoha, N. (2014). Towards proffering a solution to the persistent religious intolerance which is a bane of development in Nigeria. Global Advanced Research Journal of Educational Research and Review, 3(2), 022-027.

Ilorah, R. (2009). Ethnic bias, favouritism and development in Africa. Development Southern Africa, 26(5), 695-708.

Isaac, T. S. (2011). Religious violence in Nigeria: Causal diagnoses and strategic recommendations to the state and religious communities. Retrieved May 20, 2015, from http://www.ajol.info/index.php/ajcr/article/viewFile/78703/69042

Oduwole, T. A., \& Fadeyi, A. O. (2013). Religious fanaticism and national security in Nigeria. Journal of Sociological Research, $4(1), 49-60$.

Okpaga, A., Ugwu, S., Chijioke, E., \& Okechukwu, I. (2012). Activities of Boko haram and insecurity question in Nigeria. Arabian Journal of Business and Management Review (OMAN Chapter), 1(9), 77-99.

Ome, E. M., \& Ani, C. (2015). Re-Examining religious insecurity in the Africa state: The menace and security challenges of Boko Haram in Nigeria. Open Journal of Political Science, 1(1), 95-101.

Omoregbe, J. I. (1999). Comparative religion, Christianity and other religions in dialogue: Christianity, Judaism, Islam, African traditional religion, Hinduism, Buddhism, Jainism, Confucianism, Taoism and Shintoism. Lagos: Joja Educational Research and Publishers Limited.

Omotosho, A. O. (2003). Religious violence in Nigeria—The causes and solutions: An Islamic perspective. Swedish Missiological Theme, 1(1), 15-31.

Ottuh, J. A. (2013). The role of religion in the realization of vision 2020 in Nigeria. Research on Humanities and Social Sciences, 3(2), 6-11.

Paul, J., \& Peter, M. (2015). Defining “Religion”. (Wikipedia). Retrieved May 20, 2015 from http://www.democraticunderground.com/12646299

Salawu, B. (2010). Ethno-Religious conflicts in Nigeria: Causal analysis and proposals for new management strategies. European Journal of Social Sciences, 13(3), 345-353.

Ushe, M. U. (2012). Religious conflicts and education in Nigeria: Implications for national security. International Journal of Educational Research and Development, 1(2), 011-022.

Ushe, M. U. (2012). The role of Christian religious education in resolving Political violence in the northern states of Nigeria. Journal of Research in Education and Society, 3(1), 41-53. 